\title{
Adnexal mass: a clinicopathological study at a tertiary care centre in Assam, India
}

\author{
Mukut Jyoti Das*, Pranay Phukan
}

Department of Obstetrics and Gynecology, Assam Medical College and Hospital, Dibrugarh, Assam, India

Received: 22 January 2019

Accepted: 05 March 2019

\section{*Correspondence:}

Dr. Mukut Jyoti Das,

E-mail: mukutjyoti.d@gmail.com

Copyright: (C) the author(s), publisher and licensee Medip Academy. This is an open-access article distributed under the terms of the Creative Commons Attribution Non-Commercial License, which permits unrestricted non-commercial use, distribution, and reproduction in any medium, provided the original work is properly cited.

\begin{abstract}
Background: An adnexal mass may be found in females of all ages with significantly variable prevalence, but more common among women of reproductive age. Adnexal masses pose a special dilemma to the attending gynaecologist because the diagnosis is often difficult and differential diagnosis is vast. Clinical examination is the first step in evaluation of patients with adnexal mass. Pelvic masses which are undetected or overlooked on physical examination can be identified by Ultrasonography. The aims and objectives of the study were to: to find out different types of adnexal pathology clinically, correlation of clinical finding with histopathology, correlation of ultrasonography finding with histopathology.

Methods: The present study was carried in the Department of Obstetrics and Gynecology, Assam medical college and hospital, Dibrugarh from $1^{\text {st }}$ July 2017 to $30^{\text {th }}$ June 2018 . This study was a hospital based observational study which included 145 patients of adnexal mass attending the GOPD who required admission and operative intervention. All cases underwent an abdominal ultrasound examination with color Doppler. Transvaginal sonography was done wherever feasible. Following surgery, specimens were sent for histopathological examination and the reports were correlated with pre-operative clinical and ultrasonography findings.

Results: The most common site of origin of adnexal mass was ovary (92.41\%) followed by fallopian tube (6.20\%) and broad ligament (1.39\%). Majority (79.31\%) were non neoplastic or benign adnexal masses. All cases of adnexal malignancy were of ovarian origin. The sensitivity and specificity of clinical examination for diagnosis and discriminating benign and malignant ovarian neoplasms were $70 \%$ and $86.6 \%$ and that of ultrasonography was $86.67 \%$ and $96.65 \%$ respectively.

Conclusions: Adnexal mass in reproductive age group were mostly non neoplastic and benign, whereas malignancy was mostly seen in peri and post-menopausal age group. Ultrasonography is a useful adjunct to clinical examination for diagnosis and proper management of patients with adnexal mass in low resource setup.
\end{abstract}

Keywords: Adnexal mass, Clinical examination, Ultrasonography, Histopathology

\section{INTRODUCTION}

The term adnexa are derived from the pleural form of the Latin word "adnexus" which means "appendage". The fallopian tube and ovary and their mesenteries are so closely related anatomically that they are often collectively called the adnexum (plural=adnexa). ${ }^{1}$
Adnexal masses refer to the ovarian masses or cysts, fallopian tube masses, broad ligament pathology and Para tubal cysts. An adnexal mass may be found in females of all ages with significantly variable prevalence. Ovarian cancer is one of the commonest causes of death from gynaecological malignancy and is fifth commonest cause of cancer deaths in women. ${ }^{2}$ Fortunately, the benign 
lesions far outnumber the malignant ones. ${ }^{3}$ Adnexal masses pose a special dilemma to the attending gynaecologist because the diagnosis is often difficult and differential diagnosis is vast.

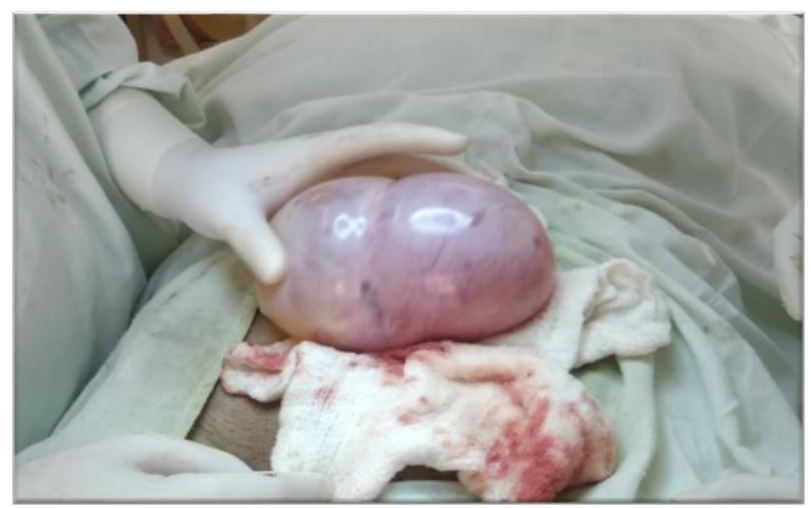

Figure 1: Mucinous cystadenoma.

A significant variation is observed among the patients who clinically presents with adnexal masses.

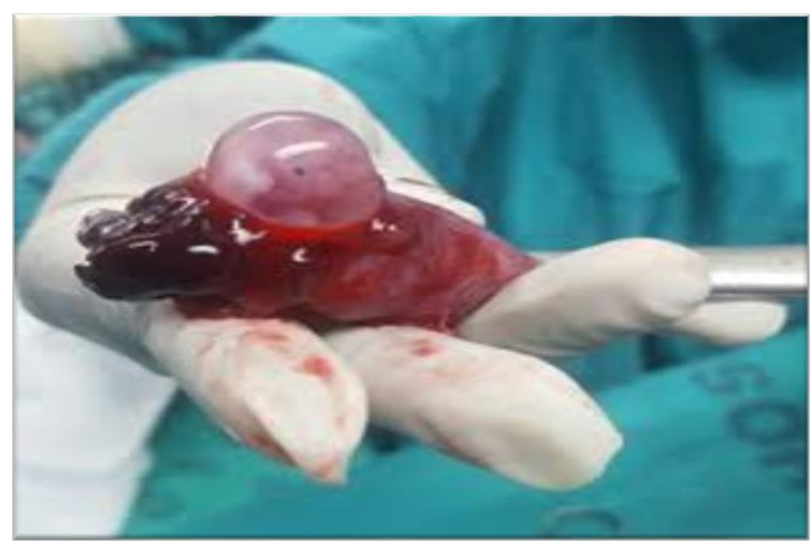

Figure 2: Ectopic pregnancy.

Some patients may be asymptomatic, some may have pain abdomen, lump abdomen, menstrual irregularities, infertility etc. while some others may present with an acute abdomen which can be due to infection, haemorrhage, torsion, rupture of ovarian cyst or ruptured ectopic pregnancy. ${ }^{4}$

It is the risk of malignancy that propels us for early, accurate and prompt diagnosis to lessen the morbidity and mortality. A thorough abdominal and pelvic examination with a high index of suspicion should be done during the initial encounter with the patient. Pelvic masses which are undetected or overlooked on physical examination can be identified by ultrasonography (USG). Transvaginal sonography is the first choice for imaging of an adnexal mass. Transvaginal technique offers highresolution imaging, especially of the adnexa. ${ }^{5,6}$

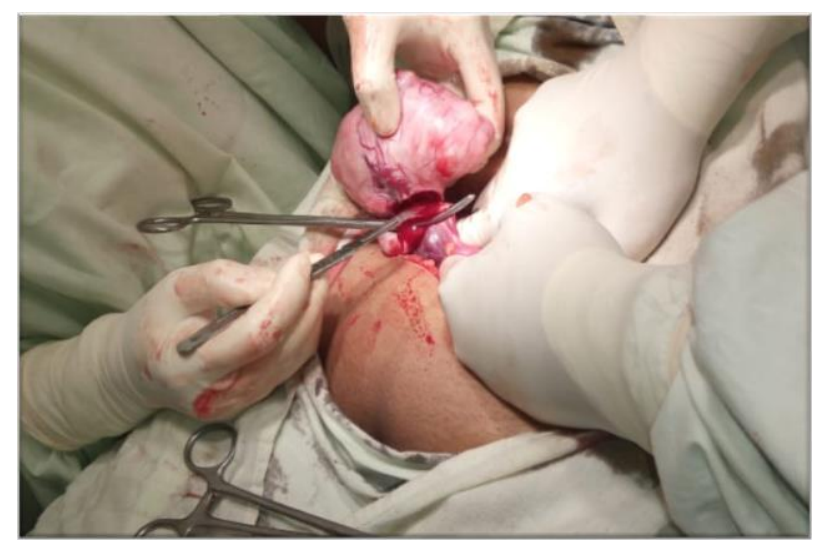

Figure 3: Serous cystadenocarcinoma.

Several studies have shown that the examiner's subjective impression has good diagnostic performance for characterizing adnexal masses by this modality., With the advancement of technology, the role of computerized tomography (CT), magnetic resonance imaging (MRI) and positron emission tomography (PET) in diagnosis and management of adnexal masses has increased vastly, but they may not be feasible in every patient in low resource set up. The advantages of USG are its wide availability, low cost, safety and simplicity of the examination. USG has been shown to be accurate for both detecting and characterizing adnexal mass as confirmed by histopathology. ${ }^{9}$

\section{METHODS}

The present study was carried in the Department of Obstetrics and Gynecology, Assam medical college and Hospital, Dibrugarh. This study was undertaken from $1^{\text {st }}$ July 2017 to $30^{\text {th }}$ June 2018 covering a total period of 1 year.

\section{Inclusion criteria}

- It was a hospital based observational study which included all patients of adnexal mass who attended the Gynecological Outpatient Department (GOPD) of Assam medical college and hospital, Dibrugarh and required admission and operative intervention.

\section{Exclusion criteria}

- Adnexal mass treated conservatively, mass arising from uterus, adnexal mass of non-gynecological origin were excluded from the study.

Detailed history about demographic factors, presenting complaints and menstrual history were obtained. Complete general physical examination and gynecological examination were performed, and provisional diagnosis was made. 
To evaluate the adnexal mass further, an ultrasound examination consisting of transabdominal and transvaginal (not done in unmarried) sonography were done. Color doppler was added in suspicious cases of malignancy where sonographic findings regarding size of adnexal mass, laterality, locularity, solid elements, hemorrhage, presence of ascites, evidence of metastasis and doppler studies with pulsatility index (PI) and resistance index $(\mathrm{RI})$ were assessed.

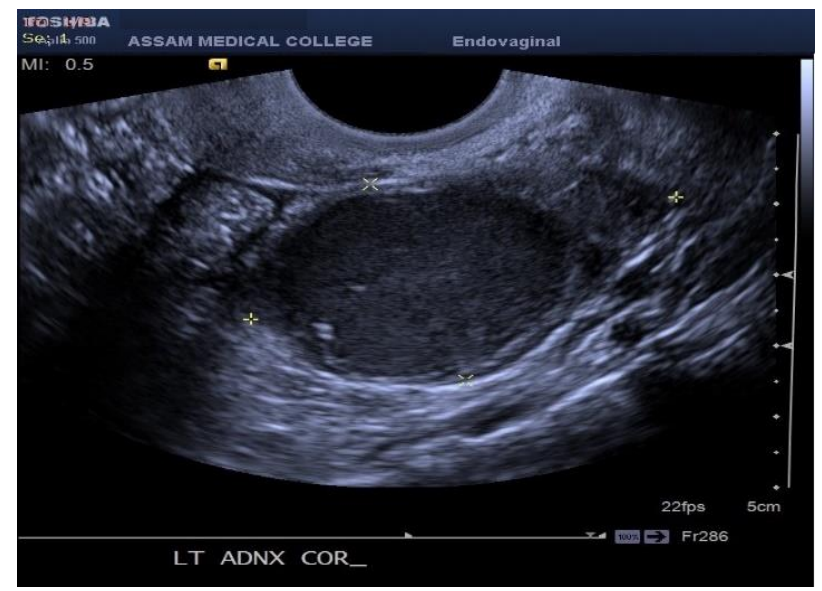

Figure 4: Endometrioma.

An ultrasound diagnosis was made. Standard laboratory tests consisting of complete hemogram, blood sugar level, liver and renal function tests and other preoperative investigations were done.

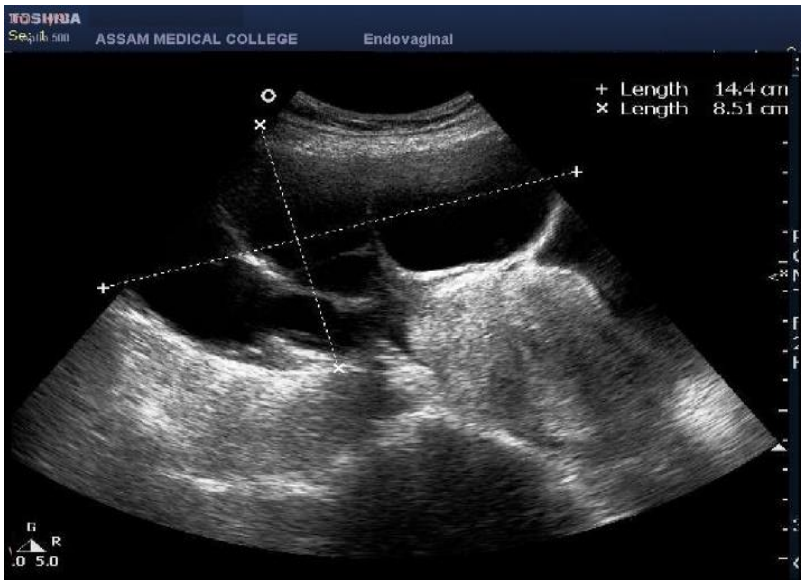

Figure 5: Mucinous cyst.

When malignancy was suspected clinically or in ultrasonography, advanced tests like CECT, MRI, tumour markers and ultrasound guided core biopsy was done where ever feasible. Laparotomy was performed. Following surgery, specimens were sent for histopathological examination and the reports were correlated with pre-operative clinical and imaging findings. The accuracy of clinical and ultrasound diagnosis was assessed.

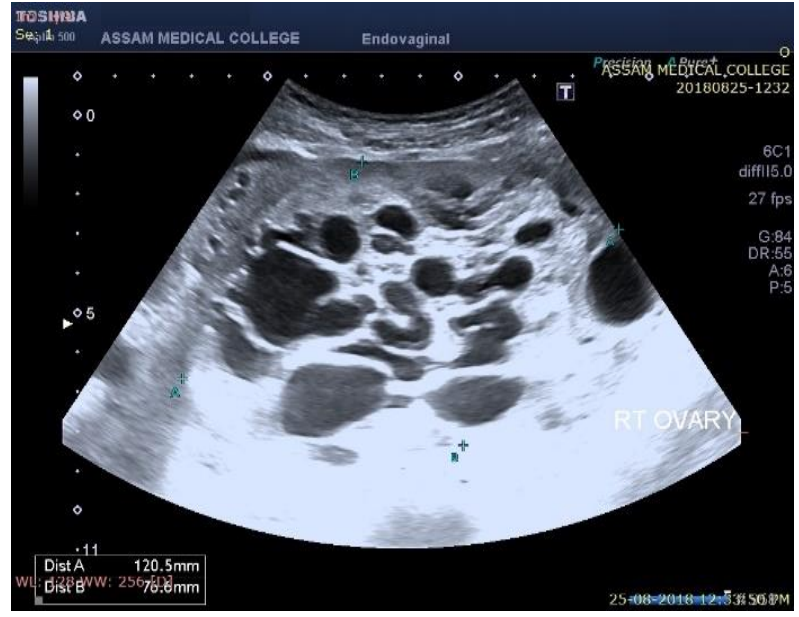

Figure 6: Serous cystadeno carcinoma.

\section{Statistical analysis}

Sensitivity, specificity, negative and positive predictive value of clinical findings and sonography were noted and tabulated using SPSS software for windows. Frequencies and percentages were calculated for categorical data. Association between groups for categorical data was calculated using chi-square test. Validity and predictive values and accuracy for the test were calculated. $\mathrm{P}<0.05$ at $95 \%$ confidence interval was considered statistically significant. Ethical committee clearance and patient consent were obtained for all cases in the study.

\section{RESULTS}

The total admissions to the gynaecology ward were 1250 during the study period. The number of cases of adnexal masses with surgical interventions were 145. The occurrence of adnexal mass in all age group was $8.62 \%$ of all gynaecological admissions and $1.08 \%$ of all patients attending the GOPD of Assam Medical College and hospital, Dibrugarh.

Table 1: Relative frequency of adnexal mass.

\begin{tabular}{|c|c|c|}
\hline Type of adnexal pathology & Number & Percentage \\
\hline \multicolumn{3}{|l|}{ Ovarian } \\
\hline Non-neoplasm & 30 & 20.68 \\
\hline Benign tumour & 74 & 51.04 \\
\hline Malignant tumour & 30 & 20.68 \\
\hline Total & 134 & 92.40 \\
\hline \multicolumn{3}{|l|}{ Fallopian tube } \\
\hline Ectopic pregnancy & 7 & 4.86 \\
\hline Hydrosalpinx & 2 & 1.37 \\
\hline Total & 9 & 6.23 \\
\hline \multicolumn{3}{|l|}{ Broad ligament } \\
\hline Fibroid (true) & 2 & 1.37 \\
\hline Total & 2 & 1.37 \\
\hline Grand total & 145 & 100.00 \\
\hline
\end{tabular}


The occurrence of adnexal mass was highest in 30-39 years of age with youngest case being 16 years and oldest case being 68 years of age. The mean age of presentation of adnexal masses was 38.11 years. (Table 1) shows the most common site of origin of adnexal mass was ovary $(92.41 \%)$ followed by fallopian tube $(6.20 \%)$ and broad ligament (1.39\%).

Among the ovarian origin adnexal masses, $20.68 \%$ were non neoplastic, $51.04 \%$ were benign neoplasms and $20.68 \%$ were malignant neoplasms. Fallopian tube pathology included ectopic pregnancy $(4.86 \%)$ and hydrosalpinx $(1.37 \%)$. Broad ligament fibroids $(1.37 \%)$ were the only broad ligament pathology detected in the study.

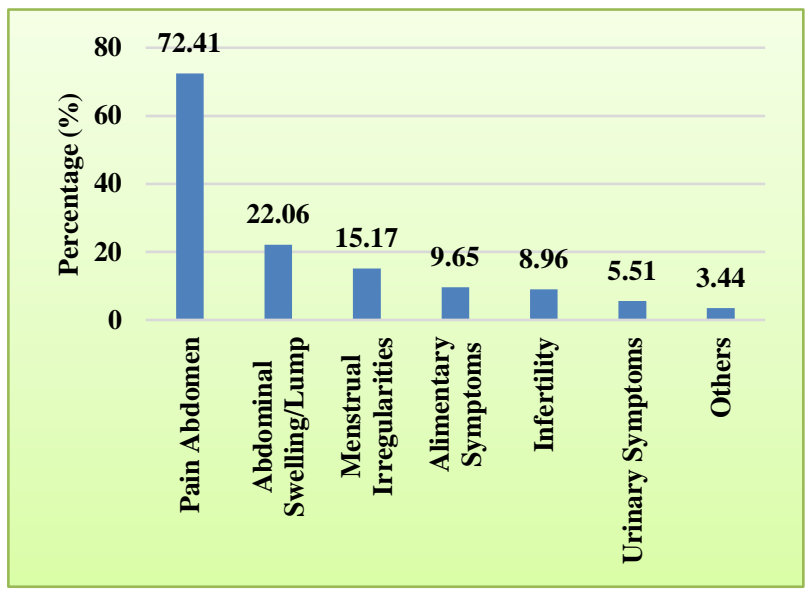

Figure 7: Clinical findings.

Figure 7 shows the relative frequency of clinical findings. The majority of patients had multiple symptoms. The most common clinical presentation in all adnexal masses were pain abdomen $(72.41 \%)$ followed by abdominal lump (22.06\%). Other complains like menstrual irregularities, infertility, urinary symptoms, alimentary symptoms, pressure symptom etc. were also found.

Out of 145 patients, $10(6.86 \%)$ patients presented to the OPD with acute abdomen. Ruptured ectopic pregnancy $(2.76 \%)$ was the most common cause followed by twisted ovarian tumor $(2.07 \%)$, ruptured endometrioma $(1.38 \%)$ and ruptured corpus luteal cyst $(0.69 \%)$. Most common complication seen in the study intraoperatively was adhesions (28.96\%) followed by haemorrhage (14.48\%).

Table 2: Non -neoplastic ovarian mass.

\begin{tabular}{|l|l|l|}
\hline Pathology & Number & Percentage \\
\hline Simple cyst & 4 & 13.33 \\
\hline Corpus luteal cyst & 7 & 23.33 \\
\hline Endometrioma & 17 & 56.67 \\
\hline $\begin{array}{l}\text { Ovarian ectopic } \\
\text { pregnancy }\end{array}$ & 2 & 6.67 \\
\hline Total & 30 & 100.00 \\
\hline
\end{tabular}

Non neoplastic ovarian masses accounted for $20.68 \%$ of adnexal masses.

Table 2 shows different non neoplastic ovarian masses.

The most common non neoplastic ovarian mass was endometrioma followed by corpus luteal cyst.

The occurrence of benign tumor in the present study was $51.04 \%$ and the most common benign tumor was serous cyst adenoma.

Table 3: Benign tumour (histology).

\begin{tabular}{|c|c|c|}
\hline Benign tumour (histology) & Number & Percentage \\
\hline \multicolumn{3}{|l|}{ Epithelial Tumor } \\
\hline Serous cyst adenoma & 31 & 41.89 \\
\hline $\begin{array}{l}\text { Papillary serous cyst } \\
\text { adenoma }\end{array}$ & 1 & 1.35 \\
\hline Mucinous cyst adenoma & 17 & 22.97 \\
\hline \multicolumn{3}{|l|}{ Germ cell tumor } \\
\hline Mature teratoma (dermoid) & 24 & 32.44 \\
\hline \multicolumn{3}{|l|}{ Sex cord stromal tumor } \\
\hline Fibroma & 1 & 1.35 \\
\hline Total & 74 & 100.00 \\
\hline
\end{tabular}

Table 3 shows different benign tumors encountered in the study.

The occurrence of malignant tumor in the present study was $20.68 \%$ and the most common malignant tumor was papillary serous cyst adenocarcinoma.

Table 4: Malignant tumour (histology).

\begin{tabular}{|l|l|l|}
\hline $\begin{array}{l}\text { Malignant tumour } \\
\text { (histology) }\end{array}$ & Number & Percentage \\
\hline Epithelial tumor & 15 & 50.00 \\
\hline $\begin{array}{l}\text { Serous cyst } \\
\text { adenocarcinoma }\end{array}$ & 1 & 3.33 \\
\hline $\begin{array}{l}\text { Papillary serous cyst } \\
\text { adenocarcinoma }\end{array}$ & 4 & 13.33 \\
\hline $\begin{array}{l}\text { Mucinous cyst } \\
\text { adenocarcinoma }\end{array}$ & 2 & 6.67 \\
\hline $\begin{array}{l}\text { Endometroid } \\
\text { carcinoma }\end{array}$ & 3 & 10.00 \\
\hline Germ cell tumor & 2 & 6.67 \\
\hline \begin{tabular}{l} 
Dysgerminoma \\
\hline $\begin{array}{l}\text { Immature } \\
\text { teratoma }\end{array}$
\end{tabular} & 1 & 3.33 \\
\hline $\begin{array}{l}\text { Embryonal cell } \\
\text { carcinoma }\end{array}$ & 2 & 6.66 \\
\hline $\begin{array}{l}\text { Metastatic } \\
\text { carcinoma }\end{array}$ & 30 & 100.00 \\
\hline Total & & \\
\hline
\end{tabular}

Table 4 shows different malignant tumors encountered in the study. 
Table 5: Clinical diagnosis versus histopathology in diagnosis of malignant tumor.

\begin{tabular}{|c|c|c|c|}
\hline \multirow{2}{*}{$\begin{array}{l}\text { Clinical } \\
\text { diagnosis }\end{array}$} & \multicolumn{2}{|c|}{$\begin{array}{l}\text { Histopathological } \\
\text { diagnosis }\end{array}$} & \multirow[t]{2}{*}{ Total } \\
\hline & $\begin{array}{l}\text { Malignancy } \\
\text { present }\end{array}$ & $\begin{array}{l}\text { Malignancy } \\
\text { absent }\end{array}$ & \\
\hline $\begin{array}{l}\text { Malignancy } \\
\text { present }\end{array}$ & 21 & 15 & 36 \\
\hline $\begin{array}{l}\text { Malignancy } \\
\text { absent }\end{array}$ & 9 & 100 & 109 \\
\hline Total & 30 & 115 & 145 \\
\hline
\end{tabular}

The chi-square statistic is 41.3566 . The $\mathrm{p}$-value is $<0.001$. This result is significant at $\mathrm{p}<0.05$.

In present study, clinical examination had a sensitivity of $70 \%$ and specificity of $86.96 \%$ in detecting malignant adnexal mass as shown in Table 5.

Table 6: Ultrasound diagnosis versus histpathology in diagnosis of malignant tumor.

\begin{tabular}{|c|c|c|c|}
\hline \multirow{2}{*}{$\begin{array}{l}\text { Ultrasound } \\
\text { diagnosis }\end{array}$} & \multicolumn{2}{|c|}{ Histopathological diagnosis } & \multirow{2}{*}{ Total } \\
\hline & $\begin{array}{l}\text { Malignancy } \\
\text { present }\end{array}$ & $\begin{array}{l}\text { Malignancy } \\
\text { absent }\end{array}$ & \\
\hline $\begin{array}{l}\text { Malignancy } \\
\text { present }\end{array}$ & 26 & 5 & 31 \\
\hline $\begin{array}{l}\text { Malignancy } \\
\text { absent }\end{array}$ & 4 & 110 & 114 \\
\hline Total & 30 & 115 & 145 \\
\hline
\end{tabular}

The chi-square statistic is 95.9222 . The $\mathrm{p}$-value is $<0.001$. This result is significant at $\mathrm{p}<0.05$.

On the other hand, ultrasonography had a sensitivity of $86.67 \%$ and specificity of $95.65 \%$ in detecting malignant adnexal mass as shown in (Table 6).

\section{DISCUSSION}

Majority of adnexal mass may regress on conservative treatment while some may require operative intervention.

There is no effective screening test to detect ovarian malignancy. ${ }^{10}$ In the present study, out of 1250 admissions in the gynecology ward, the incidence of adnexal masses undergoing surgical intervention was $8.62 \% .92 .41 \%$ were ovarian in origin of which $20.68 \%$ were non neoplastic, $20.68 \%$ were malignant and $51.04 \%$ were benign neoplasms. This is comparable to the study Ganga $\mathrm{P}$ et al, Sharma I et al, Yogambal $\mathrm{M}$ et al, who found the frequency of benign and malignant tumor to be similar. ${ }^{11-13}$

The mean age of patient with adnexal mass was 38.61 years. This is comparable to findings of Radhamani $\mathrm{S}$ et al and Bhagde $\mathrm{AD}$ et al, but more than the finding of $\mathrm{Al}$ Shukri et al. Mean age of malignant tumors was 45 years in present study. ${ }^{14-16}$ The higher percentage of malignant ovarian tumors in peri and postmenopausal women in the present study is similar to that in other studies.
In the present study, it was found that the most common benign tumor was serous cyst adenoma (41.89\%). Similar findings were observed by Kanthikar SN et al, where serous cyst adenoma was found in $35.71 \%$ cases. ${ }^{17}$ Also Sharma I et al in their study found serous cystadenoma as most common tumor (34\%). ${ }^{12}$ Most common malignant tumor was serous cyst adenocarcinoma (14.44\%) which is similar to Kanthikar SN et al, $(8.57 \%)$ and Sharma I et al, (12.74\%) where they also found serous adenocarcinoma as the most common malignant tumor. ${ }^{12,17}$

In the present study, among the non-ovarian origin adnexal masses, $9(6.2 \%)$ cases were of fallopian tube origin (7 ectopic pregnancy, 2 hydrosalpinx) and 2 $(1.37 \%)$ cases were true broad ligament fibroid. This is finding was comparable to finding of Radhamani $\mathrm{S}$ et al, but less compared to the finding of Bhagde $\mathrm{AD}$ et al, where they found $16 \%$ cases to be of fallopian tube origin. $^{14,15}$

The commonest symptom in the present study was pain abdominal and it was found to be $72.41 \%$ which was similar to other studies by $\mathrm{Al}$ shukri et al, Bhagde AD et al and Radhamani $\mathrm{S}$ et al, where they found it to be in $98 \%, 92 \%$ and $82 \%$ of cases respectively. ${ }^{14-16}$ Second most common symptom found in the present study was lump abdomen. Other symptoms included menstrual irregularities, urinary symptoms, infertility, alimentary symptoms, etc.

Sensitivity of clinical examination for distinguishing a malignant mass from a benign one is not full proof, and the results need to be confirmed with investigations. ${ }^{18}$ Clinical examination appears to have limited ability to discriminate benign from malignant adnexal masses in early stages. In the present study, the sensitivity of clinical examination in detection of malignant adnexal mass was found to be $70 \%$. This was comparable to the finding of Radhamani $\mathrm{S}$ et al, but more than the finding of Padila LA et al. ${ }^{14,19}$ Sonography (transvaginal and transabdominal) is a sensitive method for detecting adnexal mass and ovarian cancer. In the present study, the sensitivity of ultrasonography in detection of malignant adnexal mass was found to be $86.67 \%$. This finding is similar to the finding of Radhamani $\mathrm{S}$ et al and Timmerman $\mathrm{D}$ et al, who found sensitivity of ultrasonography to be $87.5 \%$ and $93 \%$ respectively. ${ }^{9,14}$

\section{CONCLUSION}

Adnexal mass in the reproductive age group were mostly non neoplastic and benign, whereas in peri and postmenopausal age group were malignant. Majority of adnexal masses were of ovarian origin. The differentiation between benign and malignant ovarian tumor is, however, a clinical challenge. Imaging plays an important role in the identification and characterization of adnexal masses and can help the clinician in determining the further course of management. Ultrasonography is an 
useful adjunct to clinical examination for diagnosis and proper management of patients with adnexal mass. The present study was able to give an insight into the burden of the disease in the population. In this era of CT scan, MRI, PET scan, Immunohistochemistry and molecular pathology, where the diagnosis is based on these highend investigations, in our institute with limited resources and low socioeconomic status of patient, the clinico morphological features were still greatest guide in the diagnosis and proper management of patients with adnexal mass.

Funding: No funding sources

Conflict of interest: None declared

Ethical approval: The study was approved by the Institutional Ethics Committee

\section{REFERENCES}

1. Jeffcoate's principles of gynaecology, $8^{\text {th }}$ edition; 2014:490-527.

2. Rauh-Hain JA, Melamed A, Buskwofie A, Schorge JO. Adnexal mass in the postmenopausal patient. Clinic Obstetr Gynecol. 2015;58(1):53-65.

3. Zaman S, Majid S, Hussain M, Chughtai O, Mahboob J, Chughtai S. A retrospective study of ovarian tumours and tumour-like lesions. J Ayub Med Coll Abbottabad. 2010; 22 (1):104-8.

4. Alcázar JL, Guerriero S, Laparte C, Ajossa S, RuizZambrana Á, Melis GB. Diagnostic performance of transvaginal gray-scale ultrasound for specific diagnosis of benign ovarian cysts in relation to menopausal status. Maturit. 2011;68(2):182-8.

5. Middleton WD, Kurtz AB, Hertzberg BS. Ultrasound: The requisites. St Louis, MI: Mosby; 2004:610.

6. Pourissa M, Refahi S, Moghangard F. The diagnostic accuracy of abdominal ultrasound imaging for detection of ovarian masses. Iran $\mathbf{J}$ Radiol 2007;4:103-7.

7. Goff BA, Mandel LS, Melancon CH, Muntz HG. Frequency of symptoms of ovarian cancer in women presenting to primary care clinics. JAMA 2004;291:2705-12.

8. Smith LH, Morris CR, Yasmeen S, Parikh-Patel A, Cress RD, Romano PS. Ovarian cancer: can we make the clinical diagnosis earlier?. Canc 2005;104:1398407.

9. Sokalska A, Timmerman D, Testa AC, Van
Holsbeke C, Lissoni AA, Leone FP, et al. Diagnostic accuracy of transvaginal ultrasound examination for assigning a specific diagnosis to adnexal masses. Ultrasound Obstetr Gynecol. 2009;34(4):462-70.

10. Jacob IJ, Menon U. Progress and challenges in screening for early detection of ovarian cancer. Mol Cell Proteomics. 2004;3:355-66.

11. Ganga P, Suneeta KP, Dhaded AV, Yenni VV. Ovarian tumours. JIMA. 2002:100 (07).

12. Sharma I, Sarma U, Dutta UC. Pathology of ovarian tumour-A hospital based study. Int J Med Sci Clin Inv. 2014;1(6):284-6.

13. Yogambal M, Arunalatha $\mathrm{P}$, Chandramouleeswari K, Palaniappan V. Ovarian tumours-incidence and distribution in a tertiary referral center in south India. IOSR-JDMS. 2014;13(2):74-80.

14. Radhamani S, Akhila MV. Evaluation of adnexal masses-correlation of clinical, sonological and histopathological findings in adnexal masses. Inter $\mathbf{J}$ Scientific Study. 2017; 4 (11): 88-92.

15. Bhagde AD, Jani SK, Patel MS, Shah SR. An analytical study of 50 women presenting with an adnexal mass. Inter J Reprod Contracept Obstetr Gynecol. 2016; 6 (1): 262-5.

16. Al-Shukri M, Mathew M, Al-Ghafri W, Al-Kalbani M, Al-Kharusi L, Gowri V. A clinicopathological study of women with adnexal masses presenting with acute symptoms. Ann Med Health Sci Res 2014; 4: 286-8.

17. Kanthikar SN, Dravid NV, Deore PN, Nikumbh DB, Suryawanshi KH. Clinico-histopathological analysis of neoplastic and non-neoplastic lesions of the ovary: a 3-year prospective study in Dhule, North Maharashtra, India. Journal of clinical and diagnostic research: JCDR. 2014;8(8):FC04.

18. Balbi GC, Musone R, Menditto A, Balbi F, Corcioni C, Calabria $\mathrm{G}$, et al. Women with a pelvic mass: indicators of malignancy. European J Gynaecol Oncol. 2001;22(6):459-62.

19. Padilla LA, Radosevich DM, Milad MP. Accuracy of the pelvic examination in detecting adnexal masses. Obstet Gynecol. 2000; 96: 593-8.

Cite this article as: Das MJ, Phukan P. Adnexal mass: a clinicopathological study at a tertiary care centre in Assam, India. Int J Reprod Contracept Obstet Gynecol 2019;8:1457-62. 